Григорій КАЗЬМИРЧУК,

доктор історичних наук, професор Дрогобицького державного педагогічного університету імені Івана Франка

(Україна, Дрогобич) kazmyrchuk@ukr.net

\title{
СУЧАСНА РОСІЙСЬКА ІСТОРІОГРАФІЯ ПЕРЕДОДНЯ І ПОЧАТКОВОГО ПЕРІОДУ ДРУГОї СВІТОВОї ВІЙнИ
}

\begin{abstract}
Стаття присвячена проблемам трактування подій початкового періоду Другої світової війни сучасною російською історіографією. 3 'ясовано ї̈ оновлене прочитання, яке виникло в результаті сочіально-політичних змін після розпаду СРСР, залучення історичною наукою нових архівних документів, плюралізму думок, зменшення контролю й тиску держави на діяльність істориків. Зроблено висновки, щяо багато питань і тем Другої світової війни отримали нове осмислення та розвиток. Проте російська національна історіографія ще не позбувалася імперського мислення, фальшування деяких важливих питань, нав'язування помилкових оцінок і висновків.
\end{abstract}

Ключова слова: сучасна російська історіографія, Друга світова війна, фальсифікаиія.

Grigorii KAZMYRCHUK, PhD hab. (History), Professor in Drohobych Ivan Franko State Pedagogical University (Drohobych, Ukraine) kazmyrchuk@ukr.net

\section{CONTEMPORARY RUSSIAN HISTORIOGRAPHY \\ ON THE THRESHOLD AND ON THE INITIAL PERIOD OF SECOND WORLD WAR}

The article is devoted to some problems of modern national Russian historiography of the Second World War. It is established that a new interpretation of them has arisen in the process of socio-political changes in the former USSR, the use of historical archival materials by historical science, pluralism of thoughts and conclusions, and a reduction in the control of state oppression by the minds and scientific work of scientists.

The Second World War is one of the key events of the twentieth century, which shocked the world community. After the end of the Second World War began to appear diverse scientific, journalistic, artistic works on individual problems of war, published letters, memories of its participants. In modern Russia, politics and historical science are closely interconnected and mutually supportive each other, serving the ruling stratum taking into account their needs and goals which they seek to achieve. During this period, high-quality critical research on the Second World War appeared in Russia. In a series of works on the basis of new archival materials little-known issues were investigated. More substantiated conclusions and hypotheses were expressed. In the new conditions, there was an urgent need to establish a credible history of the Second World War, a comprehensive study of all aspects of the initial period.

However, the events of the Second World War and their contemporary interpretation turned out to be an extremely complicated and controversial subject of research. Modern historians declare their desire to more objectively study the complex processes of the Second World War on the basis of new archival, memoir and epistolary materials. Newest $n$ historiography develops in several directions: scientific and popular. The scientific direction is characterized by the involvement of a large archival base and a complex narrative of the material. The popular direction is popular and respected by a wide audience of readers, a clear statement of materials and ideas of the authors. The founder of this direction is Viktor Suvorov, who updated the discussion aspects of the Second World War as a popular scientific material.

The views of Victor Suvorov stimulate historians actively discuss this issue in monographs and periodicals. Leading Russian historians are investigating the initial period of the Second World War. They involve in their research the achievements of Soviet historiography and characterize the historiographic heritage of foreign colleagues, determine their influence on Russian historiography.

The object of the article is analysis of available literature on important problems of the development of contemporary Russian historiographical thought devoted to the interpretation of the events of the Second World War. 
Contemporary Russian historiography absorbed many ideological cliches of Soviet historiography. Key issues of the initial period of the Second World War remained relevant. They have a special place in the problem of finding the culprit for the solution of military confrontation. Contemporary Russian historiography of the Second World War declared a desire to apply new approaches to the interpretation of the events of the initial period of the Second World War, using the latest conditions for the development of historical science, associated with pluralism of thought, the application of methodological principles of Western European historical science in the interpretation of global wars. The Russian Federation put Messianic function at World War II. It should contribute to maintaining a positive image of public construction. That is why public practices constantly use stereotypes and myths about the war for propaganda purposes. Modern Russian historical science contemptuously put to the works of colleagues from other countries. It selectively uses their results. The emergence of historiographical generalizations about the Second World War was the key to the formation of standards for an ideological order for the interpretation of the events of the war. These processes influence the interpretation of the events of the initial period of the Second World War, because as analyzing these events, one can conclude about all the perpetrators in the resolution of the war and their criminal plans and geopolitical claims on the eve of the confrontation.

Key words: contemporary Russian historiography, World War II, falsification.

Григорий КАЗЬМИРЧУК,

доктор исторических наук, профессор Дрогобыческого государственного педагогического университета имени Ивана Франко

(Украина, Дрогобыч) kazmyrchuk@ukr.net

\section{СОВРЕМЕННАЯ РОССИЙСКАЯ ИСТОРИОГРАФИЯ ПРЕДДВЕРИЯ И НАЧАЛЬНОГО ПЕРИОДА ВТОРОЙ МИРОВОЙ ВОЙНЫ}

Статья посвящзена некоторым проблемам современной национальной российской историографии Второй мировой войнь. Установлено, что новое их прочтение возникло в процессе социально-политических изменений в бывшем СССР, использования исторической наукой новых архивных материалов, плюрализму мыслей и выводов, уменьшению контроля утеснений государством на умы и научную работу ученых. Сделаны выводы, что многие вопросы и темы Второй мировой войны получили новые трактовки и оценки. Тем не менее, российская национальная историография еще не избавилась от имперского мылиления, фальсификации отдельных важных вопросов, навязывает очибочные политические оченки и выводы.

Ключевые слова: современная национальная историография, Вторая мировая война, фальсификация.

Постановка проблеми. Друга світова війна - одна 3 ключових подій XX ст., яка приголомшила світову спільноту. Після іiі завершення відбулися помітні зміни в соціально-економічному, політично-культурному вимірах, постали важливі проблеми, над якими працювали й працюють не одне покоління істориків та інших фахівців, які стараються детально й науково дослідити усі iii колізії. Саме тому після закінчення Другої світової війни почали з'являтися різножанрові наукові, публіцистичні, художні твори про окремі проблеми війни, друкувалися листи, спогади іiі учасників. Друга світова війна стала важливою історико-суспільною проблемою, яка обросла величезною кількістю праць, більшість з яких, за визначенням німецького історика І. Хоффман, перетворилася на «історіографічну макулатуру» (Хоффман, 1993: 19). Їхня кількість чисельно постійно зростає, але якість «перебуває в полоні» мілітаристської політики путінського режиму. У сучасній Росії політика і наука, у тому числі й історична, тісно пов'язані та взаємовпливають одна на одну, обслуговують панівний прошарок, враховуючи його потреби й цілі.

Аналіз досліджень. Сучасна національна історіографія країн, зокрема російська, бере свій початок із кінця 80 - початку 90-х рр. ХХ ст., коли відбувалися соціально-політичні зміни в колишньому СРСР, які «пробудили» суспільство, поглибили його зацікавленість справжньою історією, без прикрас і фальшування, без надуманих теоретико-методологічних основ. Критика, сумніви, недовіра до тих історичних досліджень, які раніше полонили історичні праці про війну, розширили зацікавленість не тільки вчених, політиків, але й простих громадян до архівних документів, до висловлювань військових і державних діячів. У Росії, як і за кордоном, у цей період з'явилися високоякісні критичні дослідження про Другу світову війну. В низці праць на основі нових ар- 
хівних матеріалів досліджувалися маловідомі питання, висловлювалися більш аргументовані висновки й гіпотези. У нових умовах виникла гостра потреба створення достовірної історії Другої світової війни, комплексного вивчення всіх аспектів початкового періоду (Золотарев, 1998: 544; Мерцалов, Мерцалова, 1993: 50; Орлов, 1993: 16-20).

Однак події Другої світової війни, та їхнє сучасне трактування виступили надзвичайно складною і суперечливою темою дослідження, оскільки жахливе протиборство війни й миру, варварства й людяності, добра й зла визначали мотивацію скоєного та шукали винуватця. Кожна держава, учасниця війни, у своїй державній політиці пам'яті намагається знайти наукове обгрунтування своїм геополітичним претензіям та меркантильним цілям, які були результатом клубка суперечностей напередодні військового протистояння.

Сучасні історики декларують своє бажання на основі нових архівних, мемуарних та епістолярних матеріалів більш об'єктивно вивчати складні процеси Другої світової війни. Новітня російська історіографія розвивається у кількох напрямках: науковому й популярному. Перший напрям характеризується залученням значної архівної бази, інколи мало читабельним викладом матеріалу. Другий - користується популярністю й повагою широкої читацької аудиторії, зрозумілим викладом матеріалів й думок авторів. Він не поступається новизною думок, часто веде й займає провідні позиції в суспільній історичній думці, зазнає крити з боку вчених-консерваторів, які шельмують авторів таких праць. Основоположником цього напрямку є Віктор Суворов (Резун Богдан Васильович), який науково-популярним викладом матеріалу актуалізував дискусійні аспекти Другої світової війни (Суворов, 1993: 351). Погляди зазначеного автора стимулюють істориків до активного обговорення даної проблематики в монографіях й періодичних виданнях та спонукають до організації конференцій. Дослідженням початкового періоду Другої світової війни займаються провідні російські історики, які залучають у своїх дослідженнях здобутки радянської історіографії та характеризують історіографічні надбання зарубіжних колег та визначають їхній вплив на російську історіографію (Суховерська, 2016: 200; Суховерська, 2017: 117). Л. Безименський, О. Гогун, М. Мельтюхов, О. Орлов, Б. Соколов, М. Семиряга, М. Солонін розглянули еволюцію російської історіографії, яка поступово розширила проблемне поле дослідження та застосувала нові методологічні підходи. Водночас, поза полем зору цих дослідників залишилося питання наукового синтезу поглядів російських та зарубіжних істориків, а також визначення напряму розвитку досліджень Другої світової війни.

Метою статті $\epsilon$ аналіз наявної літератури з важливих проблем розвитку сучасної російської історіографічної думки, присвяченої трактуванню подій Другої світової війни.

Виклад основного матеріалу. Практично щодо більшості проблем Другої світової війни присутній дискусійний пафос, бажання найбільше виявити можливих нестиковок у викладі матеріалів. Такий підхід притаманний і проблемам причин, підготовки і початкового періоду Другої світової війни. Погляди на завдання й характер війни радянського керівництва та сприйняття війни народом - це важливі та проблемні аспекти сучасної російської історіографії. Враховуючи обставини сприйняття війни людьми, які народилися після війни, усвідомлення ними ії події із книг та кінофільмів, спогадів, щоденників, листів учасників битв, сформувався зовсім інший, критичний, підхід до трактування подій, сформувалося супротивне світобачення, яке розкриває заяложений постулат кремлівських оракулів, які твердили, що у війні народ і партія були єдиним монолітом, що й сприяло перемозі радянського народу (Мельтюхов, 1994: 4-22).

Сучасна російська історіографія ввібрала чимало ідеологічних кліше радянської історіографії, а відтак актуальними залишилися ключові питання початкового періоду Другої світової війни, серед яких особливе місце посіла проблема пошуку винуватця розв'язання військового протистояння. Раніше радянська історіографія розглядала три версії винуватців початку Другої світової війни: 1) 18 вересня 1939 р. радянський уряд в офіційній ноті назвав винною у війні Польщу; 2) 30 листопада цього ж року Й. Сталін до неї додав ще дві держави - Францію і Англію, які проводили неоднозначну зовнішню політику; 3) 5 травня 1941 р. у таємній промові перед випускниками воєнних академій Й. Сталін виявив ще одну державу, яка розв'язала війну, - Німеччину. Після закінчення війни коло агресорів розширилося. Радянський вождь заявив, що Другу світову війну розпочали всі капіталістичні країни, зокрема нейтральні країни Швеція й Швейцарія. Ці 
висновки вождя довго домінували в працях радянських вчених і не підлягали сумніву й критиці. Головний військовий історик СРСР генерал-лейтенат П. А. Жилін заявляв, що «винуватцями війни були не тільки імперіалісти Німеччини, але і всього світу» (Жилин, 1985). Пояснення такому визначенню винуватця війни російською історіографією знайшов Жан Лепез, один з укладачів збірника «Міфи Другої світової війни» (Les mythes de la Seconde Guerre Mondiale, Ed Perrin). Biн вказав, що міф про напад Німеччини на СРСР - видумка Гітлера і Геббельса з метою «попередити напад Сталіна на Рейх». Цей міф проіснував до 1945 р., а потім - зник. Знову він відродився у праці Віктора Суворова. Французький історик зауважив, що міфи про Другу світову війну виступають також аргументами, які використовуються зараз у військовому конфлікті Росії з Україною (Певзнер).

Збурювачем спокою в національній сучасній історіографії Другої світової війни виступив В. Суворов, опублікувавши свою працю «Ледокол. Кто начал Вторую мировую войну», яка спочатку з'явилася на Заході, а згодом була перекладена 12 мовами, а також вийшла великим накладом в Росії та в Україні, витримавши 8 перевидань. У передмові до видання 1992 р. автор пише про складнощі у видавничій процедурі, зокрема що «прийшлось пробивати, переконувати й наполягати, доводилося забирати час і нерви у багатьох. Захищаючи свою ідею, я був вимушений огризатися, ображати і принижувати противників і опонентів, а інколи розривати горлянки» (Суворов, 1992: 8).

Після виходу книги та широкого резонансу навколо неї у засобах масової інформації, історики розпочали висловлювати свої думки про книгу, про її автора, наголошуючи на тому, що найдрібніший історичний нюанс праці В. Суворова дискусійний, насичений неординарними припущеннями й необгрунтованими тезами (Певзнер).

Однією з підвалин концепції дослідження В. Суворова є структурне історичне тло, в якому формувалася ідея війни, розкривалися форми й методи підготовки і проведення (Суворов, 1993: 15-21). Заслуговує на увагу твердження автора про агресивну сутність соціалістичних тоталітарних режимів Німеччини і СРСР, які підживлювали один одного, бажали реалізувати свої потаємні злочинні мрії, що заперечують деякі російські історики, прикриті брехливою пеленою ідеології сучасного російського політичного режиму (Суворов, 1993: 12-13).

Андрій і Людмила Мерцалови заперечують висновки В. Суворова про те, що Сталін і його оточення сприяли відродженню мілітариських сил Німеччини, які готувалися у радянських навчальних військових закладах артилеристів, танкістів і льотчиків (Саратов, Курськ), забезпечуючи німецьку військову промисловість стратегічною сировиною. На їх думку, висновки В. Суворова, що «Сталін створив Гітлера», «Сталін всіма силами підтримував нацизм» (Суворов, 1993: 12-26) не відповідає дійсності (Мерцалов, Мерцалова, 1993: 50). Цю тезу не поділяє проф. Інституту військової історії Німеччини (м. Фрайбург) Іоахім Хоффман, зокрема він зауважив, що «підписання і реалізація таємного протоколу перетворили Сталіна де-юре в «спільника» Гітлера і учасника військової агресії», надав Гітлеру рішучості загарбати Польщу (Хоффман, 1993: 19). Його погляди розділяють деякі російські історики. М. Солонін розділяє аргументи В. Суворова. зауваживши, що радянське керівництво підписало пакт Молотова-Ріббентропа через власні плани вторгнення в Європу, а головною небезпекою вважало запобігання війні. Саме з метою ліквідації цієї небезпеки Й. Сталін вирішив підписати пакт про ненапад з таємним протоколом, який розв’язав війну і зіштовхнув Німеччину з коаліцією західних держав, а Й. Сталіну повинна була надати роль арбітра та єдиного переможця військового протистояння (Солонин, 2005: 227). О. Гогун $з$ цього приводу зауважив, що в ідеологіях Німеччини та СРСР була закладена ідея зовнішньополітичної експансії, що продемонстрував пакт Молотова-Ріббентропа та таємний протокол до нього (Гогун, 2001). Б. Соколов 3 цього приводу вказав на намір Й. Сталін розпалити конфлікт Німеччини 3 Великобританією та Францією, але сам мав намір воювати з Німеччиною, щоб в ході такої війни максимально розширити зону власного впливу в Свропі (Соколов, 1998: 123).

Однак не всі російські історики розділили аргументи В. Суворова. М. Семиряга зробив висновок, що «твердження про рівну відповідальність СРСР та Німеччини за розв'язання Другої світової війни тільки тому, що в них існував «однаковий тоталітарний режим», не можна вважати переконливим, оскільки головну відповідальність за цей міжнародний злочин все ж таки 
несе правляча верхівка гітлерівської Німеччини» (Семиряга, 1992: 79). Л. Безименський визначив опосередковану провину СРСР у розв'язані конфлікту, оскільки Й. Сталін насправді побоювався війни (Безыменский, 2009: 338). О. Орлов зробив висновок, що Радянський Союз у міжвоєнний період проводив тільки мирну дипломатичну політику, а розв'язали Другу світову війну західні країни, які відхилили пропозиції радянського керівництва про створення дієвої системи колективної безпеки у Європі (Орлов, 2003: 298).

Таким чином, офіційна російська історіографія з презирством й зневагою ставилася до концептуальних основ праці не «професійного історика» Віктора Суворова, зневажливо називаючи їх постулатами. Перерахуємо три із них, визначені доктором історичних наук, провідним співробітником Інституту військової історії МО РФ О. Орловим: 1) Й. Сталін ще до приходу нацистів до влади в Німеччині вбачав в них «засіб», яким можна нанести разючий удар по «прогнивлим буржуазни демократіям»; 2) Й. Сталін, підписавши 23 серпні 1939 р. пакт про ненапад, щоб розв'язати війну в Свропі і у такий спосіб обманув А. Гітлера і втягнув його у війну проти західних країн; 3) Й. Сталін навесні 1941 р. готував напад на гітлерівську Німеччину (Орлов, 1993: 16-20).

Дискусії Д. А. Волкогонова, А. С. Орлова і А. Н. Мерцалова з В. Суворовим про виняткове значення превентивності удару з боку СРСР чи Німеччини, на думку М. І. Мельтюхова, не варта уваги. Німецький історик І. Хоффман ще у 1989 р. висунув гіпотезу, що наступальна диспозиція Червоної Армії становила серйозну загрозу Німеччині, тому Гітлер улітку 1941 р. «мав останню можливість випередити другого агресора» (Черкасов, 1990: 179). М. І. Мельтюхов вважає, що, ані Німеччина, ані Радянський Союз, не розраховували на напад противника, а тому теза про превентивні заходи неприпустима (Мельтюхов, 1994: 18). Професійні історики заперечують також тезу про винуватця розв'язання Другої світової війни в особі СРСР. В. Суворов не зміг, хоч і намагався, як твердить М. І. Мельтюхов переконати, що цю війну розпочала Німеччина (Мельтюхов, 1994: 18).

Причини поразок Радянської армії на початковому етапі аналізує генерал армії, доктор воєнних наук Махмуд Ахмедович Гарєєв. Зокрема, він виділяє одну з причин поразок - неправильне визначення радянським командуванням напрямку головного удару противника, затримка мобілізації і розгортання груп армій, а радянські війська не були приведені у бойову готовність, недооцінку військової потуги Німеччини (Гареев, 1992: 13-14). Ці думки, на думку російських істориків, покликані применшити темпи підготовки Радянського Союзу до війни. Матеріали статті M. І. Мельтюхова говорять про інше - військові частини за особовим складом практично відповідали кількісним показникам воєнного часу й були виведені на вихідні позиції (Мельтюхов, 1994: 10-14, 15).

Висновки. Таким чином, сучасна російська історіографія Другої світовою війни задекларувала бажання застосувати нові підходи до трактування подій початкового періоду Другої світової війни, використовуючи новітні умови розвитку історичної науки, пов'язані з плюралізмом думок, застосуванню методологічних принципів західноєвропейської історичної науки у трактуванні глобальних воєн. Водночас, у Російській Федерації на Другу світову війну поклали месіанську функцію збереження позитивного іміджу державного будівництва і постійно використовують стереотипи і міфи про війну в пропагандистських цілях. Відтак, сучасна російська історична наука зневажливо ставиться до праць колег з інших країн, досить вибірково використовує їхні результати. Поява історіографічних праць, у яких робиться спроба узагальнення літератури про Другу світову війну, стала запорукою формування стандартів ідеологічного замовлення на трактування подій війни. Особливо ці процеси впливають на інтерпретацію подій початкового періоду Другої світової війни, оскільки аналізуючи ці події, можна дійти висновку про всіх винуватців у розв'язанні війни та їхні злочинні замисли й геополітичні претензії напередодні протистояння.

\section{СПИСОК ВИКОРИСТАНИХ ДЖЕРЕЛ І ЛІТЕРАТУРИ}

Безыменский, 2009 - Безыменский Л. Сталин и Гитлер перед схваткой. Москва: Яуза: Эксмо, 2009. 478 с.

Гадєєв, 2007 - Гадєєв О. Російська історіографія передодня Другої світової війни // Сторінки воєнної історії України: Збірник наукових статей ІНАН України. Інститут історії України. Київ, 2007. Вип. 11. С. 10-19.

Гареев, 1992 - Гареев М. А. Об изучении истории Великой отечественной войны // Новая и новейшая история. 1992. № 1. С. 3-24. 
Гогун, 2001 - Гогун А. Упреждающий удар или агрессия? // Военная література. 2001. № 7. Режим доступу: http://militera.lib.ru/research/1/art/card32915.html.

Жилин, 1985 - Жилин П. Освободительная миссия Советских Вооружённых сил в Европе во Второй мировой войне Красная звезда. 1985. 24 сентября.

Жиряков, 2009 - Жиряков О. Ю. Імперський напрямок пострадянської російської історіографії Другої світової війни; автореф. Дис. канд. іст. наук. Миколаїв, 2009. 21 с.

Золотарев, 1998 - Золотарев В. Великая Отечественная война 1941 - 1945 гг. Военно-исторические очерки: в 4 кн. Кн. 1: Суровые испытания. М., 1998. 544 с.

Мельтюхов, 1994 - Мельтюхов М. Споры вокруг 1941 года: опыт критического осмысления одной дискуссии // Отечественная история. 1994. № 3. С. 4-22.

Мельтюхов, 2008 - Мельтюхов М. Упущенный шанс Сталина: Схватка за Европу, 1939 - 1941 гг: (Документы, факты, суждения): монографія. М.: Вече, 2008. 539 с.

Мерцалов, Мерцалова, 1993 - Мерцалов А., Мерцалова Л. «Непредсказуемое прошлое» или преднамеренная ложь // Отечественная мысль. 1993. № 6. С. 49-51.

Орлов, 1993 - Орлов А. Так кто же начал войну? // Армия. 1993. № 8. С. 16-20.

Орлов, 2003 - Орлов А. Сталин: в преддверии войны: монографія. М.: Алгоритм, 2003. 416 с.

Певзнер - Певзнер Г. Французские историки: В России Вторая мировая война всегда была идеологическим оружием. Режим доступу: https://inosmi.ru/social/20160120/235108570.html

Семиряга, 1992 - Семиряга М. Тайны сталинской дипломатии 1939 - 1941 гг. М.: Высшая школа, 1992. $303 \mathrm{c}$.

Соколов, 1998 - Соколов Б. Правда о Великой Отечественной войне: монографія. Санкт-Петербург: Алетейя, 1998. 280 с.

Солонин, 2005 - Солонин М. 22 июня, или когда началась Великая Отечественная война. М.: Яуза, Эксмо, 2005. 520 с.

Суворов, 1993 - Суворов В. Ледокол: Кто начал Вторую мировую войну?: монографія. К.: «Черкасский бизнес-центр», 1993. $351 \mathrm{c}$.

Суховерська, 2016 - Суховерська I. Мотиви підписання пакту Молотова - Ріббентропа у науковому дискурсі сучасної російської історіографії // Вісник Львівського університету. Серія Історична. 2016. Вип. 52. C. 200-210.

Суховерська, 2017 - Суховерська I. Синтетичні праці з історії Другої світової війни як репрезентант сучасної російської історіографії та державної політики пам’яті Росії // Емінак. 2017. № 3. Т. 2. С. 117-125.

Фляйшхауэр, 1991 - Фляйшхауэр И. Пакт. Гитлер, Сталин и инициатива германской дипломатии. 1938 1939: монографія. М.: Прогресс, 1991. 480 с.

Хоффман, 1993 - Хоффман, И. Подготовка Советского Союза к наступательной войне. 1941 год // Отечественная история. 1993. № 4. С. 19-31.

Черкасов, 1990 - Черкасов Н. С. «Спор историков» продолжается? // Новая и новейшая история. 1990. № 1. C. $62-71$.

\section{REFERENCES}

Bezyimenskiy, 2009 - Bezyimenskiy L. Stalin i Gitler pered skhvatkoy [Stalin and Hitler before the fight]. Moscow: Yauza: Eksmo, 2009478 s. [in Russian].

Hadieiev, 2007 - Hadieiev O. Rosiiska istoriohrafiia peredodnia Druhoi svitovoi viiny [Russian historiography of the eve of the Second World War] // Storinky voiennoi istorii Ukrainy: Zbirnyk naukovykh statei INAN Ukrainy. Instytut istorii Ukrainy. Kiev, 2007. Vyp. 11. S. 10-19. [in Ukrainian].

Gareev, 1992 - Gareev M. A. Ob izuchenii istorii Velikoy otechestvennoy voyny [On the study of the history of the Great Patriotic War] // Novaya i noveyshaya istoriya. 1992. № 1. S. 3-24. [in Russian].

Gogun, 2001 - Gogun A. «Pre-emptive strike or aggression?» [A preemptive strike or aggression?] // Voennaya IIteratura, 2001. № 7. Rezhim dostupu: http://militera.lib.ru/research/1/art/card32915.html. [in Russian].

Zhilin, 1985 - Zhilin P. Osvoboditelnaya missiya Sovetskikh Vooruzhennykh sil v Yevrope vo Vtoroy mirovoy voyne. Krasnaya zvezda. - 1985. - 24 sentyabrya. [in Russian].

Zhyriakov, 2009 - Zhyriakov O. Yu. Imperskyi napriamok postradianskoi rosiiskoi istoriohrafii Druhoi svitovoi viiny [Imperial direction of post-Soviet Russian historiography of the Second World War]; avtoref. Dys. kand. ist. nauk. Mykolaiv, 2009. 21 s. [in Russian].

Zolotarev, 1998 - Zolotarev V. Velikaya Otechestvennaya voyna 1941 - 1945 gg. Voenno-istoricheskie ocherki [The Great Patriotic War of 1941 - 1945. Military historical essays:]: v 4 kn. Kn. 1: Surovye ispytaniya. M., 1998. 544 s. [in Russian]. 
Meltyukhov, 1994 - Meltyukhov M. I. Spory vokrug 1941 goda: opyt kriticheskogo osmysleniya odnoy diskussii [Disputes around 1941: the experience of critical reflection on one discussion] // Otechestvennaya istoriya. 1994. № 3. S. 4-22 [in Russian].

Meltyukhov, 2008 - Meltyukhov M. Upushchennyy shans Stalina: Skhvatka za Yevropu, 1939 - 1941 gg.: (Dokumenty, fakty, suzhdeniya) [The missed chance of Stalin: The battle for Europe, 1939 - 1941.: (Documents, facts, judgments]: monografiya. M.: Veche, 2008. 539 s. [in Russian].

Mertsalov, Mertsalova, 1993 - Mertsalov A., Mertsalova L. «Nepredskazuemoe proshloe» ili prednamerennaya lozh [«Unpredictable past» or deliberate lie] // Otechestvennaya mysl. 1993. № 6. S. 49-51 [in Russian].

Orlov, 1993 - Orlov A. Tak kto zhe nachal voynu? [So who started the war?] // Armiya. 1993. № 8. S. 16-20. [in Russian].

Orlov, 2003 - Orlov A. Stalin: v preddverii voyny [Stalin: on the eve of the war]: monografiya. Moscow: Algoritm, 2003. 416 s. [in Russian].

Pevzner - Pevzner G. Frantsuzskie istoriki: V Rossii Vtoraya mirovaya voyna vsegda byla ideologicheskim oruzhiem [French historians: In Russia, the Second World War has always been an ideological weapon]. Rezhim dostupu: https://inosmi.ru/social/20160120/235108570.html. [in Russian].

Semiryaga, 1992 - Semiryaga M. Tayny stalinskoy diplomatii 1939 - 1941 gg. [Secrets of Stalinist diplomacy, 1939 - 1941]: monografiya. Moscow: Vyisshaya shkola,1992. 303 s. [in Russian].

Sokolov, 1998 - Sokolov B. The truth about the Great Patriotic War [The truth about the Great Patriotic War]: monografiya. St. Petersburg: Aleteyya, 1998. 280 s. [in Russian].

Solonin, 2005 - Solonin M. June 22, or when began the Great Patriotic War [June 22, or when the Great Patriotic War began]: monografiya. Moscow: Yauza, Eksmo, 2005. 520 s. [in Russian].

Suvorov, 1993 - Suvorov V. Ledokol: Kto nachal Vtoruyu mirovuyu voynu? [Icebreaker: Who started the Second World War?]: monografiya. K.: «Cherkasskiy biznes-tsentr», 1993. 351 s. [in Russian].

Sukhoverska, 2016 - Sukhoverska I. Motyvy pidpysannia paktu Molotova - Ribbentropa u naukovomu dyskursi suchasnoi rosiiskoi istoriohrafii [Motives for signing the Molotov-Ribbentrop Pact in the Scientific Discourse of Contemporary Russian Historiography] // Visnyk Lvivskoho universytetu. Seriia Istorychna. 2016. Vyp. 52. S. 200210. [in Ukrainian].

Sukhoverska, 2017 - Sukhoverska I. Syntetychni pratsi z istorii Druhoi svitovoi viiny yak reprezentant suchasnoi rosiiskoi istoriohrafii ta derzhavnoi polityky pamiati Rosii [Synthetic works on the history of the Second World War as a representative of contemporary Russian historiography and state policy of memory of Russia] // Eminak. 2017. № 3. T. 2. S. 117-125 [in Ukrainian].

Flyayshkhauer, 1991 - Flyayshkhauer I. Pakt. Gitler, Stalin i initsiativa germanskoy diplomatii. 1938 - 1939 [Pact. Hitler, Stalin and the initiative of German diplomacy. 1938 - 1939]: monografiya. M.: Progress, 1991. 480 s. [in Russian].

Khoffman, 1993 - Khoffman, I. Podgotovka Sovetskogo Soyuza k nastupatelnoy voyne. 1941 god [Preparing the Soviet Union for an offensive war. 1941] // Otechestvennaya istoriya. 1993. № 4. S. 19-31. [in Russian].

Cherkasov, 1990 - Cherkasov N. S. «Spor istorikov» prodolzhaetsya? [«The dispute of historians» continues?] // Novaya i noveyshaya istoriya. 1990. № 1. S. 62-71. [in Russian].

Стаття надійшла до редколегї̈ 22.02.2018 p. 